\title{
The Influence of Knowledge Sharing on Employee Innovation Capabilities
}

\author{
Andrew C. Ologbo (Corresponding author) \\ Faculty of Management (TO8), UniversitiTeknologi Malaysia (UTM) \\ 81310 Skudai, Johor Bahru, Malaysia \\ Email: andrewologbo@yahoo.com

\begin{abstract}
Khalil Md Nor
Faculty of Management (TO8), UniversitiTeknologi Malaysia (UTM)

81310 Skudai, Johor Bahru, Malaysia

Email:kmdnor@management.utm.my
\end{abstract}

Eugene Okyere-Kwakye

Facultyof Business and Management Studies, Koforidua Polytechnic

P. O. Box KF 981, Koforidua, Ghana

Email: eokyerekwakye2@gmail.com

Doi:10.5296/ijhrs.v5i3.8210 URL: http://dx.doi.org/10.5296/ijhrs.v5i3.8210

\begin{abstract}
Knowledge is the most vital element in innovation. According to the literature, knowledge management plays a prominent role which enables firms to leverage their innovation capabilities into product and service development. Knowledge sharing which is the important process of knowledge management is therefore crucial to enhance an employee innovation capability which is itself a component of the overall firm innovation capabilities.

Purpose: The purpose of this paper is to empirically examine the influence of knowledge sharing on employee innovation capabilities.

Design/methodology/approach: A questionnaire-based survey was employed for the data collection. A total of 204 engineers working with manufacturing firms in Malaysia participated in the survey.
\end{abstract}

Findings: The findings show that knowledge sharing influences employee innovation 
capabilities.

Keywords: Employee engagement; performance; public-sector.

\section{Introduction}

The main characteristic of a knowledge-based economy is it reliance on innovation and intellectual capital to create economic value. Since the mid-1980s radical global changes have forced organisations to look towards means of harnessing and growing their intellectual capital to achieve and sustain competitive advantage. The ways in which the intellectual capital possessed by firms is converted into innovation is now a huge concern to management (Wong and Aspinwall, 2006). In other words, the knowledge-based economy is dependent on innovation, which in itself basically linked to new knowledge creation, a process of knowledge management.

Studies conducted by (Storey and Kelly, 2002; Lin, 2001; Tsai, 2001) have shown that knowledge is the most vital element in innovation. Other studies conducted by (Jelenic, 2011; Lin, 2001), suggests knowledge management plays a prominent role in facilitating how organizations leverage their innovation capabilities, increase their profits, reduce production costs and redundancy in business processes thereby enhancing their efficiency and effectiveness. There are existing studies (Kang and Kim, 2013; Zamora and Senoo, 2013) which suggests that firms that effectively manage their organizational knowledge develops a higher level of innovation and competitive advantage.

Innovation plays a crucial role in fostering the long-term survival of firms, in determining the firm's success, sustaining its global competitiveness and it is linked with competitive advantage and economic consequences (Porter, 1990; Lau et al, 2010). Various definitions of innovation describes it as the generation of creative ideas, acceptance and implementation of such creative new ideas within the organization into processes, products or services (Anderson et al., 2004; Schulze et al., 2008). Previous research on innovation has shown a positive relationship between effective knowledge management and innovation (Smith et al., 2005; Darroch and McNaughton, 2002). Most scholars (like Storey and Kelly, 2002; Lin, 2001; Tsai, 2001) have expressed the spontaneous idea that knowledge is the most essential component in innovation. Based on these supports, this study would attempt to examine the influence of knowledge sharing on employee innovation capabilities. This paper is organized into sections discussing the conceptual issue of knowledge management, knowledge sharing, innovation capabilities, the nexus of knowledge sharing and employee innovation capabilities, methodology, findings and conclusion.

\section{Knowledge Management}

The synthesis of the term knowledge management from the existing studies (Beesley and Cooper, 2008; Nonaka and Konno, 1998; Raub and Von Wittich, 2004; Wong and Aspinwall, 2006), describes it as the processes of knowledge acquisition, knowledge creation or transfer, knowledge storage, knowledge sharing, knowledge retrieval and knowledge application. In a 
nut shell, these processes involves the collecting and identifying of useful information, transferring tacit knowledge to explicit knowledge, storing the knowledge in the repository to form organizational memory, disseminating and sharing it throughout the whole organization, as well as enabling employees to easily retrieve it and usefully apply the knowledge.

In addition, Nicolas (2004) states that knowledge management is an efficient process for creating, obtaining and distributing, controlling and use of knowledge, to maintain competitive advantage and achieve organizational aims. Knowledge management can be comprehensively described as an evolving set of organisational design, operational principles, processes, organizational structures, applications and technologies that helps knowledge workers dramatically leverage their creativity and ability to deliver business value (Gurteen, 1998). The importance of knowledge management is numerous. According to Jelenic (2011) andStorey and Kelly (2002), knowledge management plays an significant role in helping firms leverage their innovation capability, increase revenues, effectively reduce cost and redundancy, enhances organizational value and organizational performance.

Knowledge management is essentially made of four major processes known as knowledge discovery, knowledge capture, and knowledge sharing and knowledge application (Becerra-Fernandez et al., 2004). This study considers only knowledge sharing which is often described as the main process of knowledge management. Knowledge sharing is the process through which explicit or tacit knowledge is communicated among employees through the process of socialization and exchange (Nonaka, 1994; Becerra-Fernandez et al., 2004).

\subsection{Knowledge Sharing}

According to Becerra-Fernandez et al., 2004, knowledge management has four major processes namely knowledge discovery, knowledge capture, knowledge sharing and knowledge application. Among these four processes, knowledge sharing is the main process of knowledge management and it is often referred to be the most important aspect of knowledge management (Gupta et al., 2000).

Knowledge sharing involves exchanging ideas through deliberations to create new knowledge and it normally occurs whenever knowledge flow between two individuals or from an individual to a group (Ford and Chan, 2003). The knowledge flow can occur in email exchange, meetings, or other platforms (such as Intranet web pages). Knowledge sharing is a deliberate act that makes knowledge reusable by other people through knowledge transfer (Lee and Al-Hawamdeh, 2002; Ford and Chan 2003). This study would focus on knowledge sharing as the concept of knowledge donating and knowledge collecting based on Van den Hoof and Van Weenen (2004) concepts of knowledge sharing. The next section presents discussion on innovation capabilities.

\subsection{Innovation Capabilities}

Innovation capabilities is the ability of firms to generate new ideas for the development of their product and services to achieve better organizational performance and competitive advantage (King and Anderson, 2002; De Jong and Den Hartog, 2010). In this study, innovation capability is examined at the individual level rather that the organization as a 
whole. This is because individual employees plays essential roles in continuous innovation process of the overall work groups and the organization at large (See Figure 1). Innovation is an essential focus for many organizations and this is made possible by innovative employees and work groups. Employees have a wealth of tacit knowledge (Polanyi, 1966), thus mobilizing and utilizing this tacit knowledge can result in workplace innovations and a boost in firm performance (Getz and Robinson, 2003).

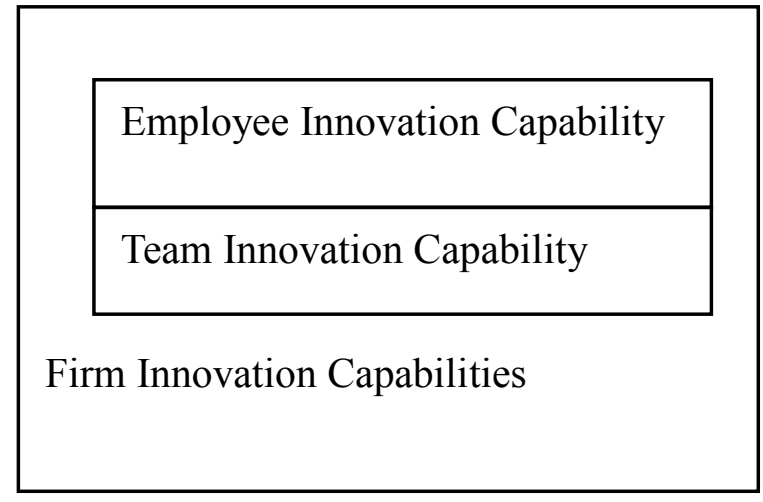

Figure 1: Components of Firm Innovation Capabilities.

Employees contribute to innovation processes across a wide range of organizations (Janssen, 2000). Firstly, they come up with new ideas. Secondly, they disseminate these new ideas as well as the ideas of others. And lastly, they work in groups to implement these new ideas. The ability of employees to continually innovate and improve products, services and work processes is increasingly becoming vital for organizations. Based on these, this study narrows down to examine employee innovation capability which is itself a component of firm innovation capabilities.

\subsubsection{Employee Innovation Capabilities: Concept Clarification}

In this study, innovation capability is examined at the individual level as the term known as employee innovation capabilities. A Capability is a routine or practices that enables employees or organizations to utilise their resources efficiently to achieve a particular goal (Lewinand Massini, 2004; Grant, 1991). Employee innovation capability is defined as that the propensity of employees to generate new ideas, promote these new ideas and implement these new ideas to achieve organizational goals (Huhtala and Parzefall, 2007). The relationship between knowledge sharing and employee innovation capabilities is thus presented in the next section.

\subsection{The Nexus of Knowledge Sharing and Employee Innovation Capabilities}

This section examines the nexus of knowledge sharing and innovation capabilities research domain which is the core of this study.In the literature, the relationship between knowledge sharing and innovation capabilities has been established. Studies conducted by scholars such as Liao et al, 2007; Lin, 2007; Song et al, 2008; Carmeloz-Ordazet al, 2011 and others have shown a positive influence of knowledge sharing on innovation capabilities. However, there is no existing study that had examined the influence of knowledge sharing on employee 
innovative capabilities. Previous studies have failed to express that in developing organizational knowledge through knowledge sharing, individual employee innovation capabilities is essential is first achieved before it sums up to the firm 's innovation capability. Therefore, this study argues that knowledge sharing is an activity that can influence employee innovation capabilities as presented in Figure 2. Hence the hypothesis stated as:

Ha: Knowledge sharing has a positive influence on employee innovation capabilities.

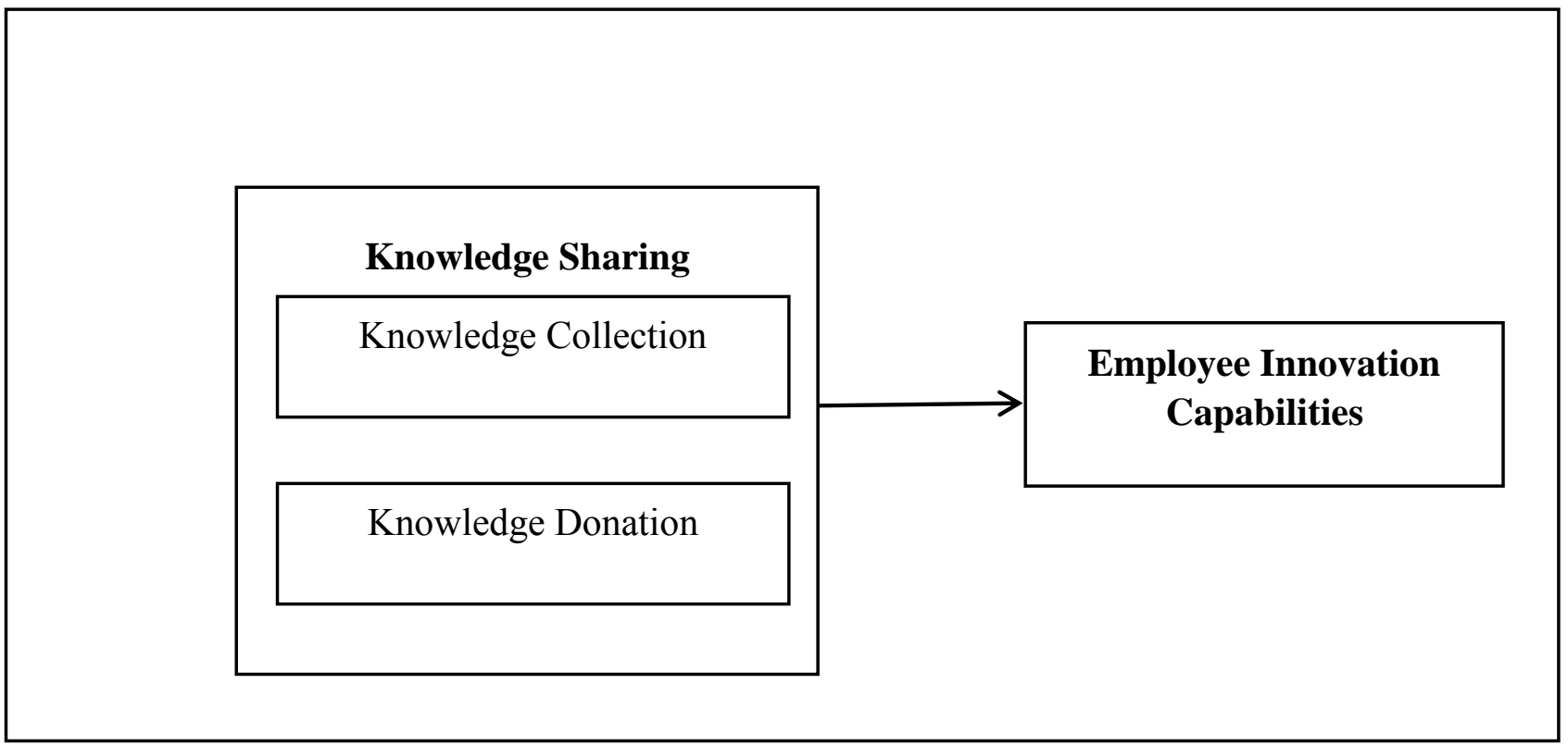

\section{Figure 2: Research Model}

\section{Methodology}

The quantitative method using survey technique was used to gather data for this study. A total of 204 engineers working with Malaysian manufacturing firms completed the survey questionnaires. The questionnaire is divided into two sections (A and B). Section A consists of questions to gather the respondents demographic profile information using a nominal scale while the section B consists of measurement items that are related to the study variables. The Likert scale is used as scale of measurement with score ranging from 1 to 5 indicating strongly disagree to strongly agree. The data was empirically tested using the multiple regression analysis with the help of SPSS software version 21. Knowledge sharing was measured by eights items adopted from Liao et al (2006) and Van den Hooff and Ridder while six measurement items used to measure employee innovation capabilities was developed by the researchers. 


\section{Findings}

As mentioned earlier, the multiple regressions using the SPSS software version 21 as the statistical tool was employed to empirically validate the data gathered. The multiple regressions are usually used to predict and weight the relationship independent variables and dependent variable. To examine the hypothesis stated in this study, the variables were entered in a single block to run the regression analysis using the SPSS software. It was found that the proposed model explains a significant percentage of variance to show the influence of knowledge sharing on employee innovation capabilities. Anova is calculated to determine if the model is a good fit for the data. The results demonstrate that the relationship between knowledge sharing and employee innovation capabilities is strong and the analysis of variance is highly statistically significant $\left(p=0.000<0.05\right.$ ). The values of $R^{2}=0.573$, Adjusted $\mathrm{R}^{2}=0.570$, Standard error of the estimate 0.48 were recorded. The summary of the result findings is presented in Table 1.

Table 1: Regression Results

\begin{tabular}{|c|c|c|c|c|c|c|c|c|}
\hline \multicolumn{3}{|c|}{ Model Summary } & \multicolumn{3}{|l|}{ Coefficients } & \multicolumn{3}{|l|}{ Anova } \\
\hline \multirow{2}{*}{$\mathrm{R}$} & \multirow{2}{*}{$\mathrm{R}^{2}$} & \multirow{2}{*}{$\begin{array}{l}\text { Adjusted } \\
\mathrm{R}\end{array}$} & \multirow[t]{2}{*}{$\begin{array}{l}\text { Standardized } \\
\text { Coefficient }\end{array}$} & \multicolumn{2}{|c|}{$\begin{array}{l}\text { Unstandardized } \\
\text { Coefficients }\end{array}$} & \multirow{2}{*}{$\mathrm{F}$} & \multirow{2}{*}{ Significance } & \multirow{2}{*}{$\mathrm{df}$} \\
\hline & & & & Beta & $\begin{array}{l}\text { Std. } \\
\text { Error }\end{array}$ & & & \\
\hline 0.757 & 0.573 & 0.570 & 0.757 & 0.792 & 0.48 & 270.594 & 0.000 & 1 \\
\hline
\end{tabular}

a. Dependent Variable: Employee Innovation Capabilities

b. Predictors: (Constant), Knowledge Sharing

\section{Discussion and Conclusion}

This study proposed a conceptual theoretical model of which a hypothesis was deduced and tested. From the results of the regression analysis, it was found that knowledge sharing has a significant effect on employeese innovation capability. In this study, employee innovation capability has been presented as the ability of the employees to generate and implement new ideas to help improve their products and services while knowledge sharing is discussed as the process of exchanging knowledge by sharing their job-related expertise, information, 
experience and know-how among employees within an organization. This study initiates the idea that knowledge sharing influences employee innovation capabilities which in turn boost the overall organizational innovation capabilities. While previous studies maintains that knowledge sharing influences firm innovation capabilities, this study suggests that the overall firm innovation capabilities is not achieved in isolation without the innovation capabilities of the individual employees working in that organization. Therefore, it is the sum total of individual employee innovation capabilities that forms the overall firm innovation capabilities. To this regard, it may not be out of context to envisage that a high level employees ${ }^{e e}$ involvement in the knowledge sharing activities in their organizations would boost the innovation capabilities of the employees. In other words, this study submits that

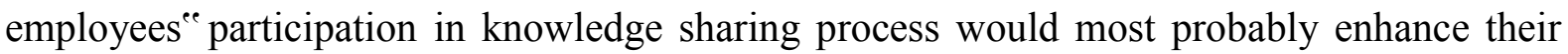
ability to generate new ideas for product and service development. Thus, it is the interplay of individuals ${ }^{e c}$ knowledge, past experience, insights and technical skills that evolve innovation. In the nutshell, knowledge sharing is critical to individuals se innovation capability. Hence, managers should provide a platform that would encourage employees to exchange their knowledge resources.

\section{References}

Anderson, N., Carsten K. W., De Dreu and Bernard A. N (2004), The routinization of innovation research: a constructively critical review of the state-of-the-science, Journal of Organizational Behaviour, 25, 147-173.

Becerra-Fernandez, I., Gonzalez, A.,andSabherwal .R. (2004), Knowledge Management: Challenges, Solutions and Technologies, New Jersey: Pearson Education Inc.

Beesley, L.G.A and Cooper, G. (2008). Defining knowledge management (KM) activities: towards consensus, Journal of knowledge management, 12 (3), 48-62.

Camelo-Ordaz C, Garcia-Cruz, J., Sousa-Ginel, E and Valle-Cabrera, R (2011), The influence of human resource management on knowledge sharing and innovation in Spain: the mediating role of affective commitment, The International Journal of Human Resource Management, 22 (7), 1442-1463.

Darroch, J. and McNaughton, R. (2002), „Examining the link between knowledge management practices and types of innovation ${ }^{\text {eee }}$, Journal of Intellectual Capital, 3 (3), $210-222$.

De Jong, J., and Den Hartog, D. (2010), Measuring innovative work behavior. Creativity and Innovation Management, 19, 23-36.

De Spiegelaere D. S., Gyes, G.V and Van Hootege, G (2012), Job Design and Innovative Work Behavior: One Size Does Not Fit All Types of Employees, Journal of Entrepreneurship, Management and Innovation, 8(4), 5-20.

De Vries, R.E, Van den Hooff, B and De Ridder, J.A (2006), Explaining Knowledge Sharing, 
Communication research, 33 (2), 115-135.

Ford, D. P., and Chan, Y. E. (2003), Knowledge sharing in a multi-cultural setting: a case study.Knowledge management research \& practice. 1(1), 11-27.

Getz, I., \& Robinson, A. G. (2003), Innovate or Die: Is that a Fact? Creativity and Innovation Management, 12(3), 130-136. doi:10.1111/1467-8691.00276.

Grant R. M., 1991, The Resource-Based Theory of Competitive Advantage: Implications for StrategyFormulation, California Management Review, 33 (3), 114-135.

Gupta, A. K., and Govindarajan, V. (2000), Knowledge management's social dimension: lesson from Nucor steel, Sloan management Review, 42 (1), 71-81.

Gurteen D. (1998), Knowledge, creativity and innovation, Journal of Knowledge Management, 2 (1) 5-13.

Huhtala, H and Parzefall, M.R(2007), A Review of Employee Well-Beingand Innovativeness: An Opportunity for a Mutual Benefit, Creativity and Innovation Management, 16(3), 299-306.

Janssen, O. (2000), Job demands, perceptions of effort-reward fairness and innovative work behaviour, Journal of Occupational and Organizational Psychology, 73, 287-302.

Jelenic, D (2011), The Importance of KnowledgeManagement in Organizations - with Emphasis on the Balanced Scorecard Learning and Growth Perspective, Proceedings of the Management, Knowledge and Learning International Conference, 33-43, Celje, Slovenia

Kang, M and Kim, B. (2013), Embedded resources and knowledge transfer among R\&D employees, Journal of Knowledge Management, 17 (5), 709-723.

Lau, A.K.W., Tang, E. and Yam, R.C.M. (2010), "Effects of supplier and customer integration on product innovation and performance: empirical evidence in Hong Kong manufacturers", Journal of Product Innovation Management, 27, 761-777.

Lee, C.K., and Al-Hawamdeh.S. (2002), Factors impacting knowledge sharing, Journal of Information and Knowledge Management, (1) 49-56.

Lewin A.Y. and Massini S., (2004), Knowledge Creation and Organizational Capabilities ofInnovating and Imitating Firms, in Tsoukas H. and Mylonopoulos N. (Eds.), Organizations asKnowledge Systems: Knowledge, Learning and Dynamic Capabilities, New York: PalgraveMacMillan, 209-237.

Liao, S., Fei W.C and Chen, C.C (2007), Knowledge Sharing, absorptive capacity, and innovation capability: an empirical study of Taiwan's knowledge-intensive industries, Journal of information Science, 33(3), 340-359.

Lin, H.F (2007), Knowledge sharing and firm innovation capability: an empirical study, International Journal of Manpower, 28 (3/4), 315-332.

Lin, I. (2001), "Innovation in the networked world", in Hamilton, B.(Ed.), Innovation and 
Imagination at Work, McGraw-Hill, Sydney, 1-16.

Nicolas, R (2004), "Knowledge management impacts on decision making process", Journal of Knowledge Management, 8 (10), 20 - 31.

Nonaka, I. (1994), “A dynamic theory of organizational knowledge creation”, Organization Science, 5(1), 14-37.

Nonaka, I., and Konno, N. (1998), The Concept of „Ba ${ }^{\text {ee }}$ : Building a Foundation for Knowledge Creation, California Management Review, 40 (3), 40-54.

Polanyi, M. (1966), The Tacit Dimension. New York: Anchor Day Books.

Porter, M.E., 1990. Competitive Advantage: Creating and Sustaining Superior Performance. New York, The Press Press, pp. 57-68.

Schulze, P., Heinemann, F. and Abedin, A. (2008), "Balancing exploitation and exploration organizational antecedents and performance effects of ambidexterity", Best Paper Proceedings - Academy of Management (AOM) Annual Meeting, Anaheim, CA, 1-6.

Smith, K.G., Collins, C.J. and Clark, K.D. (2005), "Existing knowledge, knowledge creation, capability, and the rate of new product introduction in high-technology firms", Academy of Management Journal, 48 (2), 346-57.

Song, Z.H, Fan, L.B, and Chen, S (2008), Knowledge sharing and Innovation Capability: Does Absorptive Capacity Function as a Mediator? International Conference on Management Science \& Engineering $\left(15^{\text {th }}\right)$ September 10-12, Long Beach, USA.

Storey, C. and Kelly, D. (2002), "Innovation in services: the need for knowledge management", Australasian Marketing Journal, 10 (1), 59-70.

Tsai, W. (2001), "Knowledge transfer in intra-organizational networks: effects of network position and absorptive capacity on business innovation and performance", Academy ofManagement Journal, 44 (5), 996-1004.

Van den Hooff, B. and Van Weenen, F.D.L. (2004), "Knowledge sharing in context: the influence of organizational commitment, communication climate and CMC use on knowledge sharing", Journal of Knowledge Management, 8(6), 117-30.

Wong, K.Y. and Aspinwall, E. (2006), „,Development of a knowledge management initiative and system: a case study ${ }^{\text {eee }}$ Expert Systems with Applications, 30 (4), 633-41.

Zamora, J.Z and Senoo, D (2013), Synthesizing seeming incompatibilities to foster knowledge creation and innovation, Journal of Knowledge Management, 17 (1), 106-122. 